\title{
Impact of geographic variations of the convective and dehydration center on stratospheric water vapor over the Asian monsoon region
}

\author{
Kai Zhang ${ }^{1}$, Rong $\mathrm{Fu}^{1}$, Tao Wang ${ }^{2, \mathrm{a}}$, and Yimin Liu ${ }^{3}$ \\ ${ }^{1}$ Jackson School of Geosciences, The University of Texas at Austin, Austin, Texas, USA \\ ${ }^{2}$ Department of Atmospheric Sciences, Texas A\&M University, College Station, Texas, USA \\ ${ }^{3}$ State Key Laboratory of Numerical Modeling for Atmospheric Sciences and Geophysical Fluid Dynamics, \\ Institute of Atmospheric Physics, Chinese Academy of Sciences, Beijing, China \\ ${ }^{a}$ now at: Jet Propulsion Laboratory, California Institute of Technology, Pasadena, California, USA
}

Correspondence to: Kai Zhang (kzkaizhang@utexas.edu)

Received: 9 January 2016 - Published in Atmos. Chem. Phys. Discuss.: 19 January 2016

Revised: 26 April 2016 - Accepted: 10 June 2016 - Published: 27 June 2016

\begin{abstract}
The Asian monsoon region is the most prominent moisture center of water vapor in the lower stratosphere (LS) during boreal summer. Previous studies have suggested that the transport of water vapor to the Asian monsoon LS is controlled by dehydration temperatures and convection mainly over the Bay of Bengal and Southeast Asia. However, there is a clear geographic variation of convection associated with the seasonal and intra-seasonal variations of the Asian monsoon circulation, and the relative influence of such a geographic variation of convection vs. the variation of local dehydration temperatures on water vapor transport is still not clear. Using satellite observations from the Aura Microwave Limb Sounder (MLS) and a domain-filling forward trajectory model, we show that almost half of the seasonal water vapor increase in the Asian monsoon LS are attributable to geographic variations of convection and resultant variations of the dehydration center, of which the influence is comparable to the influence of the local dehydration temperature increase. In particular, dehydration temperatures are coldest over the southeast and warmest over the northwest Asian monsoon region. Although the convective center is located over Southeast Asia, an anomalous increase of convection over the northwest Asia monsoon region increases local diabatic heating in the tropopause layer and air masses entering the LS are dehydrated at relatively warmer temperatures. Due to warmer dehydration temperatures, anomalously moist air enters the LS and moves eastward along the northern flank of the monsoon anticyclonic flow, leading to wet anomalies in the LS over the Asian monsoon region. Likewise, when con-
\end{abstract}

vection increases over the Southeast Asia monsoon region, dry anomalies appear in the LS. On a seasonal scale, this feature is associated with the monsoon circulation, convection and diabatic heating marching towards the northwest Asia monsoon region from June to August. The march of convection leads to an increasing fraction of the air mass to be dehydrated at warmer temperatures over the northwest Asia monsoon region. Work presented here confirms the dominant role of temperatures on water vapor variations and emphasizes that further studies should take geographic variations of the dehydration center into consideration when studying water vapor variations in the LS as it is linked to changes of convection and large-scale circulation patterns.

\section{Introduction}

Water vapor variation in the lower stratosphere (LS) contributes significantly to global climate change through altering the radiation budget (Forster et al., 1999; Solomon et al., 2010; Dessler et al., 2013) and chemical processes, particularly ozone depletion (Evans et al., 1998; Dvortsov and Solomon, 2001; Shindell, 2001; Stenke and Grewe, 2005; Anderson et al., 2012). Water vapor in the LS exhibits a localized maximum over the Asian monsoon region from May to September (Rosenlof et al., 1997; Randel et al., 2001; Dessler and Sherwood, 2004; Milz et al., 2005; Park et al., 2007; Randel et al., 2015). This center of maximum water vapor is an important moisture source for the global strato- 
sphere (e.g., Randel et al., 2001; Gettelman et al., 2004; Ploeger et al., 2013), although its contribution relative to that of the tropical LS is still a subject of active research (Rosenlof et al., 1997; Fueglistaler et al., 2005; Wright et al., 2011). Global models have suggested the importance of the Asian monsoon for water vapor transport to the tropics and global stratosphere (Dethof et al., 1999; Bannister et al., 2004; Gettelman et al., 2004; Ploeger et al., 2013). Therefore, it is important to understand the processes controlling transport of water vapor into the Asian monsoon LS.

The maximum LS water vapor concentration in the Asian summer monsoon region is a result of convective transport of moist air trapped by strong monsoon anticyclonic circulation (Dunkerton, 1995; Jackson et al., 1998; Dethof et al., 1999; Park et al., 2007; Ploeger et al., 2015). However, these convective transport pathways are still debatable. Convection within the Asian monsoon region predominantly reaches about $200 \mathrm{hPa}$ ( $\sim 12.5 \mathrm{~km}$ above sea-level) (e.g., Fu et al., 2006; Park et al., 2007; Wright et al., 2011). Moist air transported by convection at this level would be dehydrated as it slowly ascends to the tropopause (Holton and Gettelman, 2001). Consequently, the occurrence of deep convection is less correlated with the variation of water vapor in the LS than in the upper troposphere within the Asian monsoon region (Park et al., 2007).

The relative impact of convection and temperatures on LS water vapor variations is an ongoing study. Fu et al. (2006) suggested that deep convection over the Tibetan Plateau and south slope of the Himalayas can reach the tropopause more frequently. They proposed that the deep convection (in combination with warmer tropopause temperatures) could be the main source of water vapor for the LS over the Asian monsoon region. Some studies suggest that water vapor can be transported into the LS via direct convective injection over the Bay of Bengal and Southeast Asia (Park et al., 2007; James et al., 2008; Devasthale and Fueglistaler, 2010). Wright et al. (2011) compared the relative contributions of three distinct convective regimes within Southeast Asia (i.e., South Asian subcontinent, the South China and Philippine Seas, and the Tibetan Plateau and South Slope of the Himalayas) to the seasonal variation of water vapor in the tropical LS. They concluded that air parcels emanating from convection over the Tibetan Plateau were most moist but least numerous; air parcels originating from convection over Southeast Asia and the tropical tropopause were driest but most prominent summer source of tropospheric air to the tropical stratosphere.

Recently, Randel et al. (2015) showed that there is a dominant influence of temperatures over the southeastern flank of the Asian anticyclone on intra-seasonal variations of stratospheric water vapor over the Asian monsoon regions; overshooting deep convection was found to play a relatively minor role. However, seasonal temperature changes in this region cannot fully explain the continuous increase of LS water vapor in the Asian monsoon region during summertime, as will be shown in this paper. Besides, there is a clear geographic variation of convection associated with the seasonal and intra-seasonal variations of the Asian monsoon circulation. However, the relative influence of such geographic variation of convection vs. the variation of local dehydration temperatures on water vapor transport is still not clear. In this study, we aim to clarify this question and the role of convection by analyzing water vapor transport based on the Aura Microwave Limb Sounder (MLS) daily observations and a domain-filling forward trajectory model.

\section{Data and methodology}

In order to examine the relationships between water vapor, temperatures and convection over the summertime Asian monsoon region, we analyze water vapor observations from the Aura MLS and outgoing longwave radiation (OLR) from NOAA (National Oceanic and Atmospheric Administration) for the 2005-2013 boreal summers (May-September). We grid level 2 version 3.3 daily MLS water vapor to $10^{\circ} \times 5^{\circ}$ longitude by latitude from 215 to $100 \mathrm{hPa}$. Within this vertical range, the MLS $\mathrm{H}_{2} \mathrm{O}$ precisions are $0.5-0.9$ ppmv, ranging from $15 \%$ at $100 \mathrm{hPa}$ to $40 \%$ at $215 \mathrm{hPa}$ (Livesey et al., 2011). NOAA interpolated daily OLR in $2.5^{\circ} \times 2.5^{\circ}$ horizontal resolution is used as a proxy for convection. The diabatic heating data used for analysis is from the European Centre for Medium-Range Weather Forecasts (ECMWF) Interim Re-Analysis (ERA-Interim) archive (output from the reanalysis model forecast fields) (Dee et al., 2011). Singular value decomposition (SVD) (Bretherton et al., 1992) is applied to the covariance matrix between daily anomalies of water vapor and OLR to objectively identify the coupled patterns and the maximum covariance.

We use a domain-filling forward trajectory model to identify the water vapor transport pathways over the summertime Asian monsoon region. The trajectory model used here follows the description from Schoeberl and Dessler (2011), with trajectory integration calculated from Bowman trajectory code (Bowman, 1993; Bowman et al., 2013). Two trajectory runs driven by different circulation and temperature fields from two reanalyses are compared to evaluate the uncertainties: (1) ERA-Interim fields (Dee et al., 2011), denoted as traj_ERAi; (2) Modern Era Retrospective Analysis for Research and Applications (MERRA) fields (Rienecker et al., 2011), denoted as traj_MERRA. Previous studies have shown that this model is able to simulate both water vapor (Schoeberl and Dessler, 2011; Schoeberl et al., 2012, 2013; Wang et al., 2015) and chemical tracers (Wang et al., 2014) in the LS very well. In this study, we analyze results from diabatic runs in isentropic coordinates, in which the potential temperature tendency is converted from the diabatic heating rates as vertical velocity. Parcels are initialized at the tropical $370 \mathrm{~K}$ isentropic level, which is above the level of zero radiative heating ( $\sim 355-365 \mathrm{~K})$ (Gettelman et al., 2002$)$ but 
below the tropical tropopause $(\sim 375-380 \mathrm{~K})$. Along the trajectory integration, we use $100 \%$ saturation level with respect to ice to remove excess of water vapor instantly, i.e., the "instant dehydration", which has been proven effective in simulating stratospheric water vapor (e.g., Fueglistaler et al., 2005; Schoeberl et al., 2014). In this study, we screen all the air parcels in the Asian monsoon region at $100 \mathrm{hPa}$ each day and determine their "most recent dehydration" (MRD) statistics. The term MRD is used to indicate the most recent dehydration event along the historical travel path of an air parcel before it reaches $100 \mathrm{hPa}$. Therefore, the MRD statistics solely determine the amount of water vapor for each air parcel in the trajectory model. Details of parcel initialization and removal criterion for water vapor along the trajectories can be found in Wang et al. (2015). Water vapor in the trajectory model have been gridded and weighted by the weighting matrix of the MLS averaging kernels for fair comparison. Since the trajectory model has larger uncertainties in simulating water vapor below $100 \mathrm{hPa}$, we applied weighting functions only to levels above $100 \mathrm{hPa}$. This would cause some dry biases compared with MLS values, which will be discussed case by case in the results part.

\section{Results}

\subsection{Seasonal enhancement of LS water vapor over the Asian monsoon region}

During boreal summer, there is an isolated moisture center observed in the LS over the Asian monsoon region (Rosenlof et al., 1997; Randel et al., 2001; Dessler and Sherwood, 2004; Milz et al., 2005; Park et al., 2007; Randel et al., 2015), primarily at 100 and $82 \mathrm{hPa}$ but weakened at higher levels based on the Aura MLS observations. In this study, we use $100 \mathrm{hPa}$ to represent the LS over the Asian monsoon region. LS water vapor increases continuously throughout the summertime from May to August (e.g., Randel et al., 2015) as shown by the black line in Fig. 1. Similar temporal variations - although containing dry biases - can also be simulated by the trajectory model (blue and green lines in Fig. 1), in which water vapor is determined by temperatures at MRD locations. The outputs are weighted vertically by excluding the simulated values below $100 \mathrm{hPa}$. This makes water vapor values slightly lower than those in the Aura MLS due to less convective influences from air below. The agreement between the trajectory model simulations and observations of water vapor variations imply that temperatures, rather than convective injection, dominate the observed seasonal enhancement over the Asian monsoon region. Both observations and trajectory model simulations of the Asian monsoon show that dehydration primarily occurs on the cold (equatorward) side of the LS anticyclonic circulation (Wright et al., 2011; Randel et al., 2015). However, the seasonal changes of $100 \mathrm{hPa}$ temperatures over the southeastern flank of the anticyclone

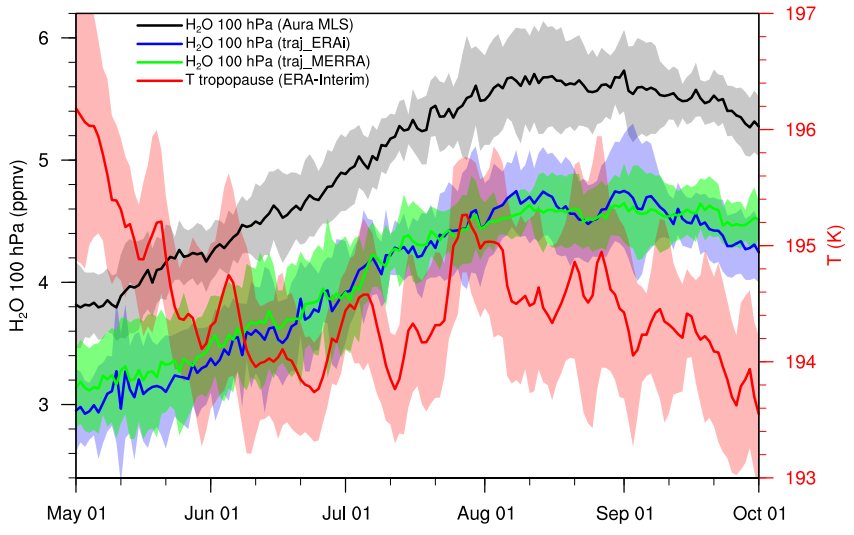

Figure 1. Climatological $100 \mathrm{hPa}$ water vapor observed by the Aura MLS (black) and simulated by the traj_ERAi (blue) and traj_MERRA (green). The time series were averaged over the Asian monsoon region $\left(20-40^{\circ} \mathrm{N}, 40-140^{\circ} \mathrm{E}\right)$ during May-September, 2005-2013. The red line denotes the time series of tropopause temperatures averaged over the same domain as in R15 (15-30 N, 70$\left.120^{\circ} \mathrm{E}\right)$, calculated based on the World Meteorological Organization (WMO) tropopause definition. The shadings indicate the corresponding standard deviation intervals.

$\left(15-30^{\circ} \mathrm{N}, 70-120^{\circ} \mathrm{E}\right.$, the red line in Fig. 1), which are expected to dominate dehydration of the LS over the Asian monsoon region (Randel et al., 2015), do not increase concurrently with water vapor from May to August. Therefore, temperatures at this location cannot fully explain the continuous increase of water vapor in the LS of the Asian monsoon region from early to late summer.

To identify the temperature-controlled areas for each month, we use the trajectory model to determine the MRD locations for all the air parcels at $100 \mathrm{hPa}$ over the Asian monsoon region $\left(20-40^{\circ} \mathrm{N}, 40-140^{\circ} \mathrm{E}\right)$. Figure $2 \mathrm{a}-\mathrm{d}$ shows the probability density distribution of the MRD locations during May to August (white contours) and the average tropopause temperatures (color shadings). A common feature is that dehydration mostly occurs on the cold (equatorward) side of the Asian monsoon anticyclonic circulation, consistent with Wright et al. (2011). This behavior of dehydration through the cold temperatures is similar to the freeze-drying process near the cold-point tropopause over the western Pacific (Holton et al., 1995; Holton and Gettelman, 2001). During May, most of the air parcels are dehydrated over Southeast Asia, where temperatures are lower than other Asian monsoon areas. The center of dehydration shifts north-westward to the Bay of Bengal in June (Fig. 2b), expands to the Bay of Bengal/north India in July (Fig. 2c) and finally shifts to north India during August (Fig. 2d). Figure 2e shows the time series of tropopause temperatures following the dehydration locations in both traj_ERAi and traj_MERRA; these were calculated by weighting tropopause temperatures based on time-varying MRD frequency statistics for each day. The continuous increase of weighted tropopause temperatures is 

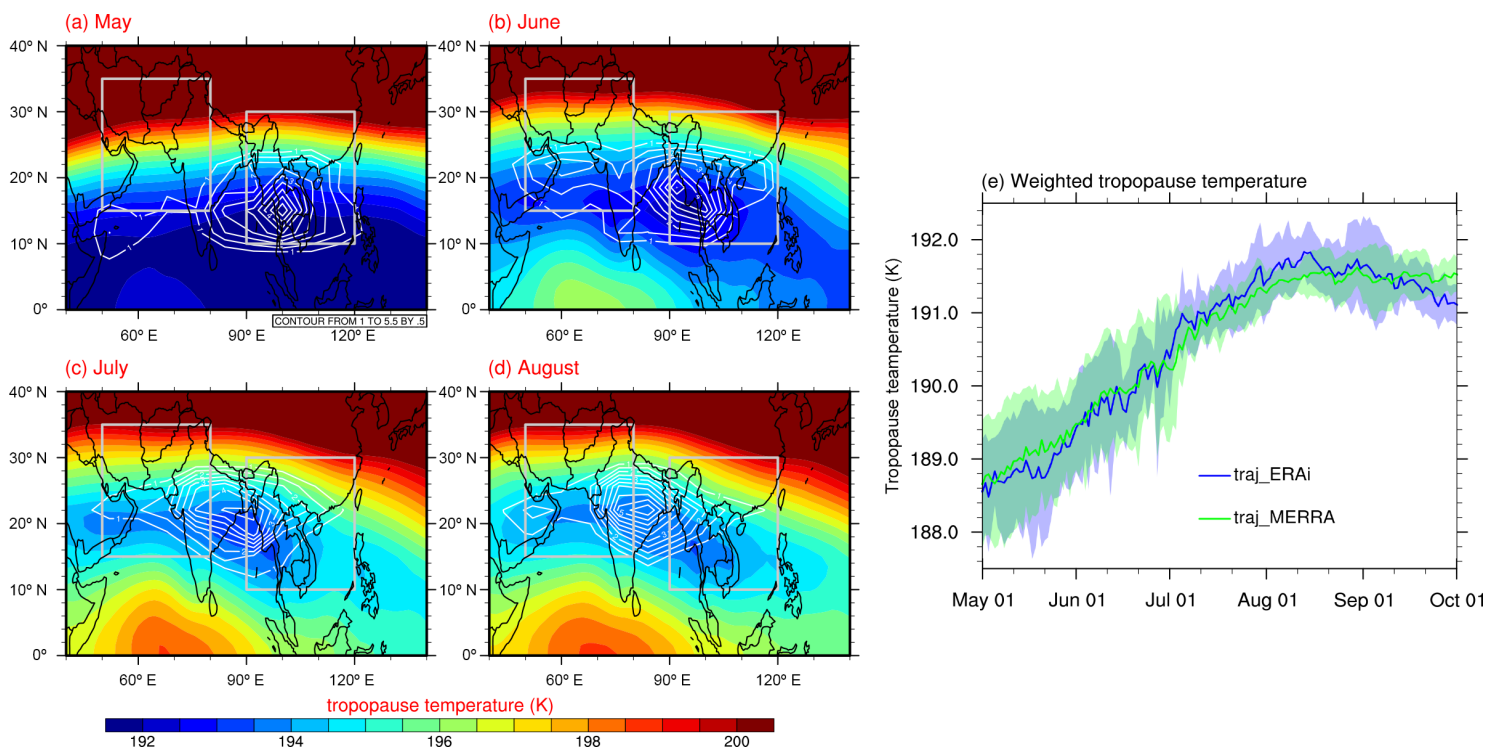

Figure 2. (a-d) Probability density distributions of last dehydration locations for air parcels located at $100 \mathrm{hPa}$ over the Asian monsoon region during May to August derived from traj_ERAi (white contours from 1 to $5.5 \%$ with an interval of $0.5 \%$ ). Color shadings are averaged tropopause temperatures in ERA-Interim. The two boxes are the two domains distinguishing the west and east side of the Asian monsoon region in Fig. 3. (e) The average tropopause temperatures weighted by the dehydration frequency distributions in traj_ERAi (blue) and traj_MERRA (green) respectively. The color shadings indicate the corresponding standard deviation intervals.

consistent with the seasonal increase of $100 \mathrm{hPa}$ water vapor shown in Fig. 1. A statistical view of the westward shift of dehydration is shown in Fig. 3a. From early to late summer, the fraction of air parcels that are dehydrated over the west side of the Asian monsoon region (red line) increases gradually but decreases over the east side (blue line). During September, the dehydration starts to retreat from the west side towards the east side. The domains for the west side and east side are outlined in the grey boxes in Fig. 2. Tropopause temperatures are generally warmer over the west side compared to the east side of the Asian monsoon region (Fig. 3b). Thus, as dehydration shifts westward toward warmer temperatures, more water vapor can enter the LS over the Asian monsoon region. Within each domain, dehydration locations vary from early to late summer, which leads to a continuous increase of the weighted tropopause temperatures shown in Fig. $3 b$ and similar to Fig. 2e.

In order to quantify the relative impact of geographic variations of the dehydration center and local temperature changes on water vapor increase from June to August, we conduct three idealized experiments based on traj_ERAi and traj_MERRA (Table 1). Taking traj_ERAi as an example, we set our control experiment (CTL) to the dehydration pattern (i.e., MRD locations) and temperatures observed in June. When only temperatures are changed to those observed in August (Exp_TEM), the averaged water vapor in the Asian monsoon LS is increased by an average of $\sim 0.49 \mathrm{ppmv}$ (where the standard deviation is $\sigma=0.21 \mathrm{ppmv}$ ). This suggests a moistening effect of the local dehydration tempera- ture changes from June to August. Similarly, when the dehydration pattern is modified by replacing the dehydration locations during June by those in August, while keeping the dehydration temperatures unchanged from those of June (Exp_LOC), the averaged water vapor is increased by on average $\sim 0.59 \mathrm{ppmv}(\sigma=0.24 \mathrm{ppmv})$. This also shows a moistening effect of the geographic shift of dehydration center from June to August. These combined moistening effects cause the average water vapor during August to be approximately 4.81 ppmv (Exp_TEM_LOC). Thus, the westward geographic shift of the dehydration center toward warmer temperatures over the western Asian monsoon region could contribute to a significant increase of the total LS water vapor from June to August; this is comparable to the contribution of the local temperature changes. Results from traj_MERRA are consistent with traj_ERAi even when accounting for minor differences (Table 1). However, both trajectory runs indicate that the westward shift of dehydration significantly enhances water vapor in the Asian monsoon LS from early to late summer. These idealized experiments indicate that we may underestimate the water vapor variations solely based on the large-scale temperature changes without considering the changes of dehydration statistics associated with the largescale circulation changes.

Diabatic heating, which drives the vertical transport in the trajectory model, also shows a westward shift with stronger enhancement of rising motion over the west side of the Asian monsoon region during August compared to that of May and June (Fig. 4). This suggests a westward migration of verti- 
Table 1. Three idealized experiments based on traj_ERAi (values in bold) and traj_MERRA (values in brackets) to quantify the relative contributions of dehydration shift and dehydration temperatures on averaged water vapor over the Asian monsoon region.

\begin{tabular}{lllr}
\hline Experiments & $\begin{array}{l}\text { Dehydration } \\
\text { pattern }\end{array}$ & $\begin{array}{l}\text { Dehydration } \\
\text { temperatures }\end{array}$ & $\begin{array}{r}\text { Averaged water } \\
\text { vapor (unit: ppmv) }\end{array}$ \\
\hline CTL & June & June & $\mathbf{3 . 7 1}(3.80)$ \\
Exp_TEM & June & August & $\mathbf{4 . 2 0}(4.16)$ \\
Exp_LOC & August & June & $\mathbf{4 . 3 0}(4.22)$ \\
Exp_TEM_LOC & August & August & $\mathbf{4 . 8 1}(4.71)$ \\
\hline
\end{tabular}
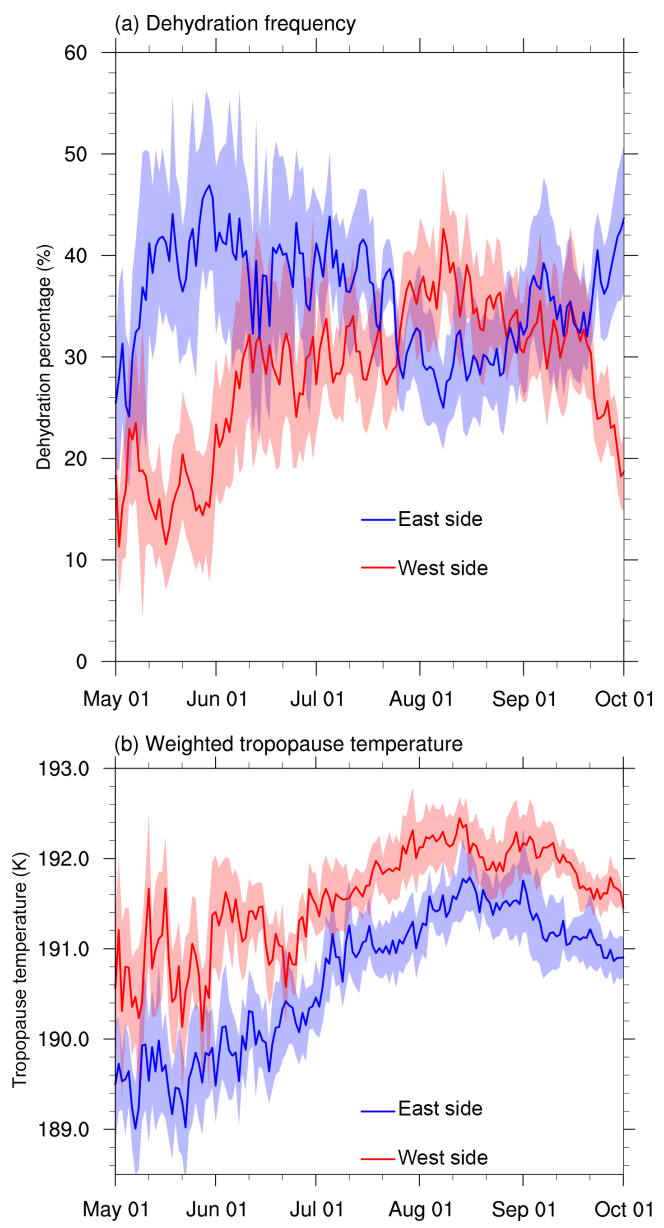

Figure 3. (a) Climatological time series of percentage of dehydration $(\%)$ located over the west side $\left(15-35^{\circ} \mathrm{N}, 50-80^{\circ} \mathrm{E}\right.$, red line) and the east side $\left(10-30^{\circ} \mathrm{N}, 90-120^{\circ} \mathrm{E}\right.$, blue line) for air parcels located at $100 \mathrm{hPa}$ over the Asian monsoon region based on traj_ERAi. (b) Average tropopause temperatures weighted by the dehydration frequency distributions over the west side and the east side respectively based on traj_ERAi. The color shadings indicate the corresponding standard deviation intervals.

cal transport associated with a gradual increase (decrease) of convection over the northwestern (southeastern) Asian monsoon region from early to late summer. Such an anomalous shift of convection and diabatic heating near the tropopause

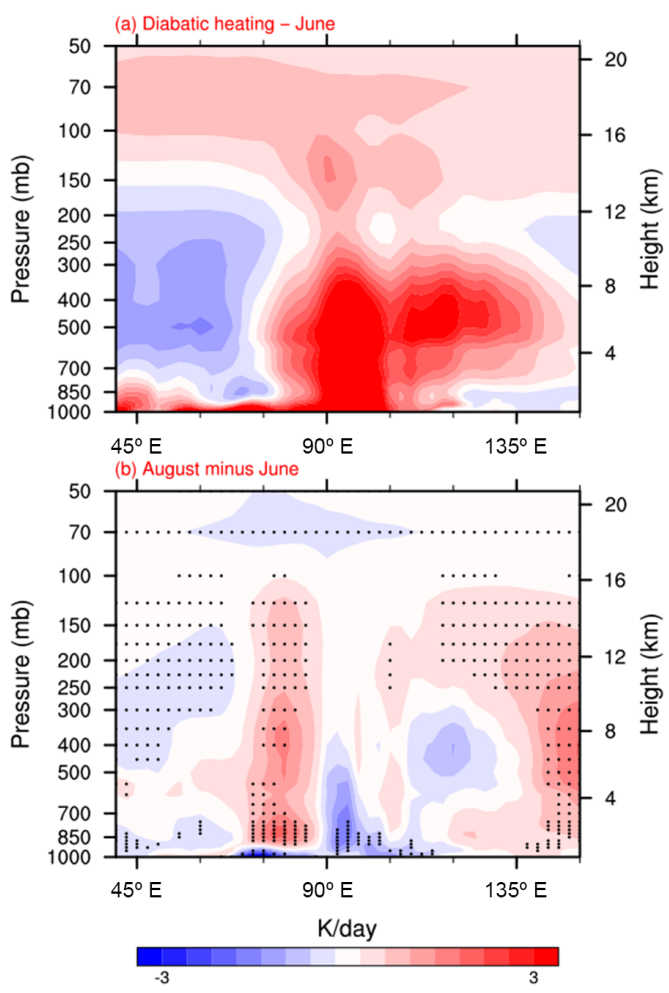

Figure 4. Vertical-longitude distribution of climatological diabatic heating averaged within $15-30^{\circ} \mathrm{N}$ in ERA-Interim for (a) June; (b) difference between August and June. The differences that are significant at $95 \%$ level based on student $t$ test are dotted.

towards the northwest side is a common feature over the Asian monsoon region during the boreal summer (e.g., Qian and Lee, 2000). This leads to an increasing fraction of air mass in the LS coming from the warmer west section of the Asian monsoon region.

\subsection{Intra-seasonal variations of $L S$ water vapor over the Asian monsoon region}

To evaluate the relationships between the lower stratospheric water vapor variation, convection and diabatic heating objectively, we applied SVD analysis to the data as described in Sect. 2. Figure 5 shows the dominant mode of SVD for MLS water vapor anomalies in the UT/LS and OLR anomalies. 
(a) $100 \mathrm{hPa} \mathrm{H}_{2} \mathrm{O}$ - heterogeneous SVD Mode $1 \quad 42.63 \%$

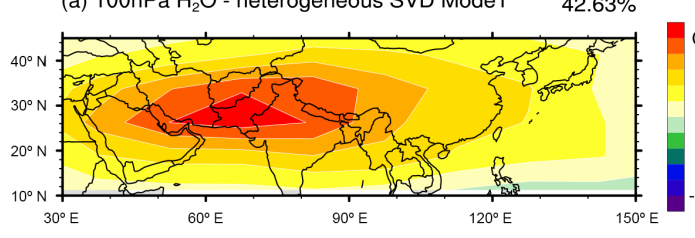

(c) Dehydration frequency - heterogeneous map

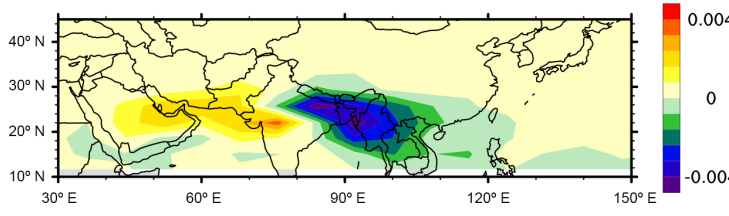

(e) OLR - homogeneous SVD Mode1

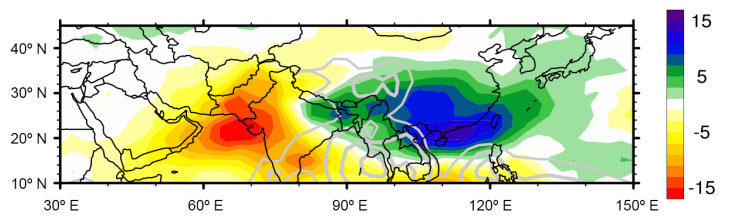

(f) Time series Mode1 (b) $147 \mathrm{hPa} \mathrm{H}_{2} \mathrm{O}$ - heterogeneous map on OLR Mode1
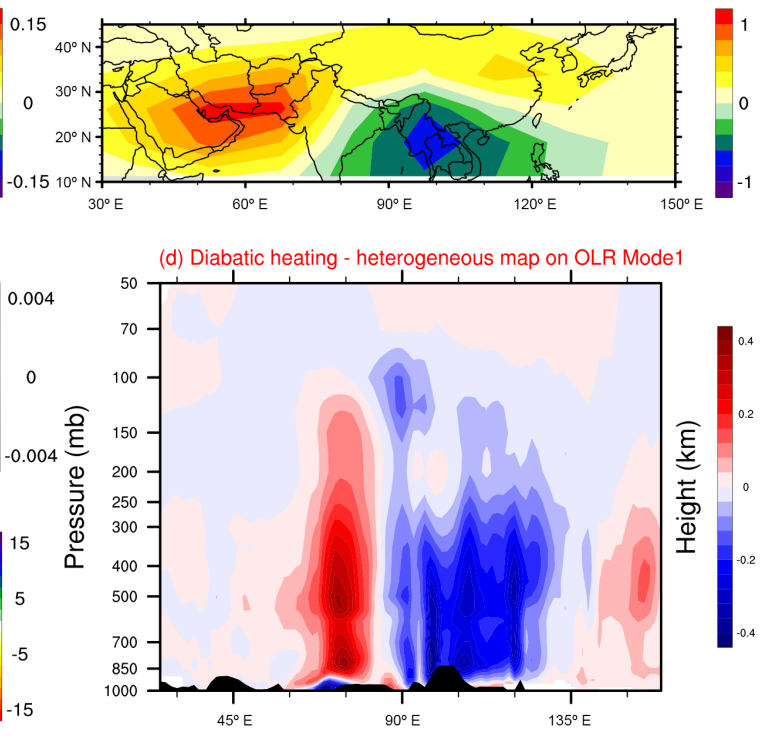

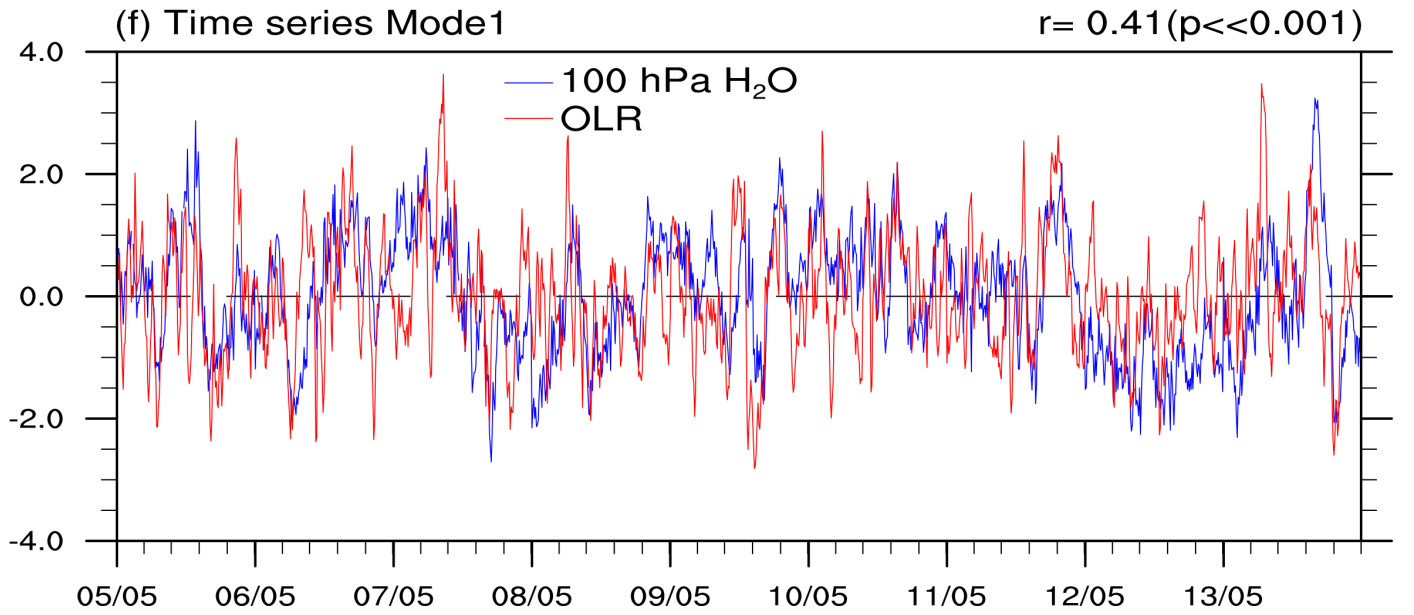

Figure 5. First SVD mode between water vapor anomalies (ppmv) and OLR anomalies $\left(\mathrm{W} \mathrm{m}^{-2}\right.$ ) over the Asian monsoon region. (a, b) Heterogeneous map of water vapor at 100 and $147 \mathrm{hPa}$ on OLR SVD mode 1; (c) heterogeneous map of dehydration frequency derived from traj_ERAi on OLR SVD mode 1; (d) heterogeneous map of diabatic heating at $25^{\circ} \mathrm{N}$ on OLR SVD mode 1; (e) homogeneous map of OLR SVD mode 1; (f) standardized time series of $100 \mathrm{hPa}$ water vapor anomalies and OLR anomalies. Note that the color bar for OLR is reversed.

The pattern of water vapor anomalies at $100 \mathrm{hPa}$ in Fig. 5a shows uniform anomalies over the entire Asian monsoon region with largest values over the western region. The corresponding OLR anomaly pattern (Fig. 5d) illustrates a zonal east-west dipole pattern, i.e., anomalously strong convection in the southwest and anomalously weak convection in the southeast of the Asian monsoon region, respectively. The statistics of the first SVD mode confirm that water vapor anomalies at $100 \mathrm{hPa}$ over the Asian monsoon region during summer are significantly correlated with OLR anomalies $(r=0.41, p<0.01)$. This first SVD mode accounts for a significant $42.63 \%$ of the total water vapor variance. By regressing $147 \mathrm{hPa}$ water vapor anomalies onto the principal component of the OLR SVD mode, we obtain the heterogeneous map of water vapor anomalies at $147 \mathrm{hPa}$ (Fig. 5b).
Due to the westward shift of convection, there is anomalously higher humidity in the entire UT over the southwestern Asian monsoon region, where an increase of cirrus clouds also occurs based on Cloud-Aerosol Lidar and Infrared Pathfinder Satellite Observations (CALIPSO) observations from 2006 to 2013 (not shown here). The heterogeneous maps of diabatic heating and dehydration frequency anomalies are consistent with the westward shift of convection, suggesting the latter probably enhances ascending motion and therefore the fraction of air mass being dehydrated over the western Asian monsoon region (Fig. 5c-d). The consistent wet anomalies from the UT to the LS - along with enhanced diabatic heating and dehydration over the western Asian monsoon region - suggest that the increase of LS water vapor over the Asian monsoon region is associated with enhanced water va- 

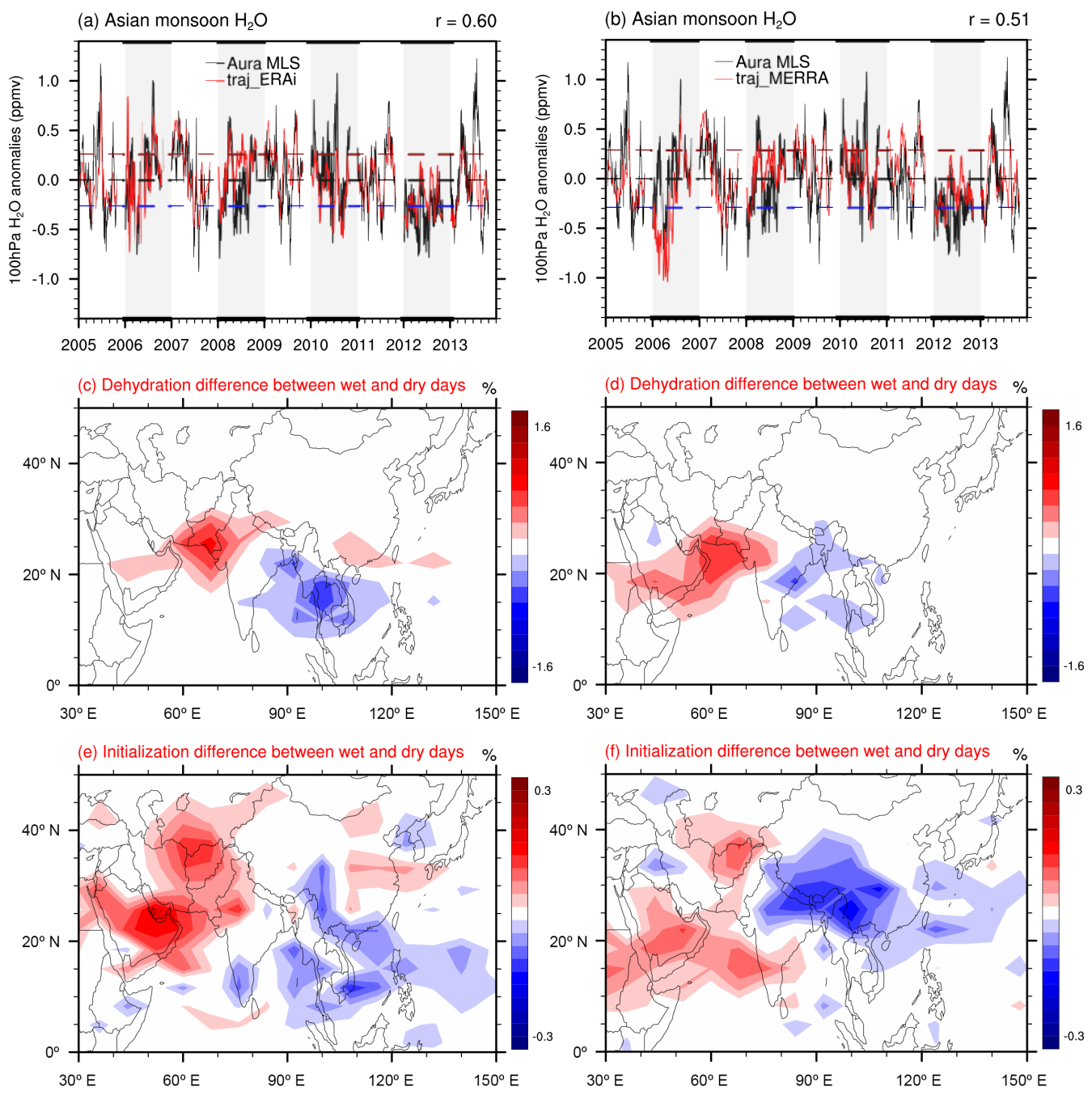

Figure 6. Left panel is from traj_ERAi, right panel is from traj_MERRA. (a, b) Time series of deseasonalized $100 \mathrm{hPa}$ water vapor anomalies in the Asian monsoon region ( $\left.20-40^{\circ} \mathrm{N}, 40-140^{\circ} \mathrm{E}\right)$ derived from Aura MLS observations (black line) and trajectory runs (red line). Dashed lines are at one sigma variability for water vapor time series in trajectory runs, and are used to identify wet and dry event (above and below 1 standard deviation, denoted by the red and blue dashed lines). (c, d) Anomalous frequency of occurrence of the last dehydration locations between wet and dry days for air parcels located at $100 \mathrm{hPa}$ over the Asian monsoon region. (e, f) Same as panels (c, d) but for initialized locations.

por transport driven by anomalous convective diabatic heating over the western monsoon region.

To further look at the intra-seasonal oscillation of the dehydration center associated with the LS water vapor changes, we compared the behavior of MRD locations during wet and dry days (Fig. 6). We use the trajectory runs to identify the MRD locations for all the air parcels at $100 \mathrm{hPa}$ in the Asian monsoon region during wet and dry days, respectively, and compare their differences. We first evaluate the performance of the model simulation on $100 \mathrm{hPa}$ water vapor variations over the Asian monsoon region $\left(20-40^{\circ} \mathrm{N}, 40-140^{\circ} \mathrm{E}\right)$. Figure $6 \mathrm{a}-\mathrm{b}$ show the time series of $100 \mathrm{hPa}$ water vapor anomalies in the Asian monsoon region during summer from the trajectory runs (red line) compared with the Aura MLS ob- servations (black line, same as Fig. 4a in Randel et al., 2015). The trajectory model can simulate both interannual and intraseasonal variations of water vapor in the Asian monsoon very well ( $r=0.6$ for traj_ERAi and $r=0.51$ for traj_MERRA), including most wet and dry extremes, which also further confirms the dominant role of temperatures on controlling the LS water vapor variations. The traj_MERRA has larger biases during 2006 compared to traj_ERAi, which leads to the relatively low correlation with the observations. The correlations shown here could also be impacted by excluding the simulated values at lower levels when the MLS weighting matrix is applied to the trajectory outputs. By selecting the wet and dry events (those above and below 1 standard deviation, denoted by the red and blue dashed lines) in the trajectory runs, 
we further investigate the different dehydration and initialization behavior during different moist states in the LS. As shown in Fig. 6c-d, there is more dehydration over the western Asian monsoon region and less over the eastern region during the wet events compared with dry events, implying a westward shift of dehydration. The underlying initialization behavior at $370 \mathrm{~K}$ also shows a westward shift of the air source with more air from the west side and less air from the east side during wet events than dry events (Fig. 6e-f). The clear westward shift of initialization and dehydration activities during wet events is consistent with the observational results of enhanced water vapor transport over the west side shown in Fig. 5. This west-east oscillation of vertical transport is associated with changes of the large-scale circulation forced by diabatic heating in the trajectory model. These results are consistent between traj_ERAi and traj_MERRA, which further confirms the robust physical links between convection, dehydration and water vapor transport. It is important to consider the west-east oscillations of the anomalous convective activity and dehydration center, in order to fully explain the changes of the LS water vapor at both seasonal and intra-seasonal timescales.

\section{Conclusions and discussion}

Water vapor in the Asian monsoon LS significantly influences water vapor of the global stratosphere (Dethof et al., 1999; Bannister et al., 2004; Gettelman et al., 2004; Ploeger et al., 2013), but significant uncertainty still exists as to what processes control its transport. This paper clarifies that the changes of dehydration locations - in addition to the changes of local dehydration temperatures - have significant influence on water vapor transport to the LS through a joint analysis of satellite data and trajectory model simulations. Although our focus is at $100 \mathrm{hPa}$, we have also examined the results for water vapor variations at $82 \mathrm{hPa}$ and found similar results.

First, our results confirm the dominant role of temperatures on the LS water vapor variations (Figs. 1, 2e and 6a-b). This is consistent with the study of Randel et al. (2015) in terms of temperature control of water vapor that enters the lower stratosphere. However, our study suggests that aside from local temperatures changes, the variation of the dehydration locations plays a significant role in both the intraseasonal and early-to-late summer moistening of the LS over the Asian monsoon region, especially its west-east oscillation. In particular, the dehydration locations vary with time and are characterized by a westward migration from the Southeast Asia monsoon region with colder temperatures in May to northwestern India with warmer temperatures in August (Figs. 2-3). The geographic shift of the dehydration center to the western Asian monsoon region with warmer tropopause temperatures could increase water vapor significantly. This is comparable to the influence of local temper- ature changes (Table 1). This sub-seasonal migration of dehydration is associated with a westward migration of vertical motion (as shown in Fig. 4), which corresponds to the seasonal march of the Asian monsoon convective systems (e.g., Qian and Lee, 2000). Second, we confirm the physical link between convection, diabatic heating and large-scale transport. At an intra-seasonal timescale, the westward shift of convection appears to enhance the diabatic heating and the ascending motion in the tropopause layer. This in turn enhances the vertical transport of water vapor and dehydration frequency over the west side of the Asian monsoon region. The less dehydrated air ascends and travels eastward, eventually increasing LS water vapor over the entire Asian monsoon region (Fig. 5). Additional transport and dehydration under warmer tropopause temperatures in the west of the Asian monsoon region would contribute to the wet anomalies in the LS (Fig. 6). The east-west oscillation of convection and dehydration patterns is similar to the well-known Boreal Summer Intraseasonal Oscillation in the Asian monsoon region (e.g., Lau and Chan, 1986; Lawrence and Webster, 2002; Kikuchi et al., 2012), which suggests a link between large-scale monsoon circulation and water vapor transport into the LS. In summary, our study suggests that water vapor transport to the LS is controlled by both tropopause temperatures and the geographic variations of the dehydration center driven by diabatic heating of convection over the Asian monsoon region.

The majority of the moist air is from the dehydration over the western Asian monsoon region where the temperatures are warmer than the cold-point tropopause temperatures over Southeast Asia. However, the source region of the moist air remains unclear. The Bay of Bengal and Southeast Asia have previously been identified as primary source regions of air parcels over the Asian monsoon LS due to frequent and deep convective protrusions (Park et al., 2007; James et al., 2008; Devasthale and Fueglistaler, 2010). Some of the air from this region detrains in the upper troposphere and is advected south-westward (e.g., Park et al., 2009). This could possibly contribute to the moist air entering the LS over the western Asian monsoon region shown in this study. Meanwhile, some of the air entering the LS over the Bay of Bengal and Southeast Asia is dry mostly due to the substantial dehydration by cold-point temperatures.

This study implies that geographic changes in convection patterns within the South Asian monsoon region could change the abundance of water vapor in the LS of the Asian monsoon without changing the strength of convection. For example, a westward convection shift would likely enhance water vapor transport through a warmer pathway from the UT to the LS over the west side of the Asian monsoon region. Some studies indicate long-term changes in precipitation over the western and surrounding regions in the past decades (e.g., Ramanathan et al., 2005; Goswami et al., 2006; Gautam et al., 2009; Bollasina et al., 2011; Turner and Annamalai, 2012; Zuo et al., 2013; Walker et al., 2015). However 
these changes are not clearly evident due to large discrepancies between different datasets (Walker et al., 2015). How these changes influence LS water vapor is also unknown. Moreover, further research is required to evaluate how seasonal and long-term dehydration statistical changes over the Asian monsoon influence the water vapor mixing ratio entering the global stratosphere. Therefore, studies of convection regime variation will have important implications for predicting future stratospheric water vapor changes in the Asian monsoon regions, and possibly over the globe.

\section{Data availability}

MLS data were obtained from the MLS web site (http://mls.jpl.nasa.gov/products/h2o_product.php; NASA, 2011), the gridded OLR data from NOAA-CIRES Climate Diagnosis Center (http://www.cdc.noaa.gov/; NOAA, 1996). The ERA-Interim data were retrieved via ECMWF Web API (https://software.ecmwf.int/wiki/display/WEBAPI/ Access+ECMWF+Public+Datasets; ECMWF, 2011). The data are available upon request by contacting Kai Zhang (kzkaizhang@utexas.edu).

Acknowledgements. We sincerely thank William J. Randel and Mijeong Park for their comments and discussions that lead to significant improvement in this work. We appreciate Kenneth P. Bowman's work on developing the trajectory code, and we thank Mark R. Schoeberl and Andrew E. Dessler for designing and developing the trajectory simulation system that is implemented by Tao Wang for simulations in this study. We thank Peirong Lin for improvements on figures and writing. We would also like to acknowledge the editorial assistance from Rachael Isphording and Adam Papendieck. Kai Zhang and Rong Fu were supported by NASA Aura Science Team Grant (No. NNX11AE72G). Yimin Liu is supported by the National Science Foundation of China (NSFC 91437219).

Edited by: P. Haynes

\section{References}

Anderson, J. G., Wilmouth, D. M., Smith, J. B., and Sayres, D. S.: UV dosage levels in summer: increased risk of ozone loss from convectively injected water vapor, Science, 337, 835-839, 2012.

Bannister, R., O'Neill, A., Gregory, A., and Nissen, K.: The role of the south-east Asian monsoon and other seasonal features in creating the "tape-recorder" signal in the Unified Model, Q. J. Roy. Meteor. Soc., 130, 1531-1554, 2004.

Bollasina, M. A., Ming, Y., and Ramaswamy, V.: Anthropogenic aerosols and the weakening of the South Asian summer monsoon, Science, 334, 502-505, 2011.

Bowman, K. P.: Large-scale isentropic mixing properties of the Antarctic polar vortex from analyzed winds, J. Geophys. Res.Atmos., 98, 23013-23027, 1993.
Bowman, K. P., Lin, J. C., Stohl, A., Draxler, R., Konopka, P., Andrews, A., and Brunner, D.: Input Data Requirements for Lagrangian Trajectory Models, B. Am. Meteorol. Soc., 94, 10511058, doi:10.1175/bams-d-12-00076.1, 2013.

Bretherton, C. S., Smith, C., and Wallace, J. M.: An intercomparison of methods for finding coupled patterns in climate data, J. Climate, 5, 541-560, 1992.

Dee, D. P., Uppala, S. M., Simmons, A. J., Berrisford, P., Poli, P., Kobayashi, S., Andrae, U., Balmaseda, M. A., Balsamo, G., and Bauer, P.: The ERA-Interim reanalysis: Configuration and performance of the data assimilation system, Q. J. Roy. Meteor. Soc., 137, 553-597, 2011.

Dessler, A. E. and Sherwood, S. C.: Effect of convection on the summertime extratropical lower stratosphere, J. Geophys. Res., 109, D23301, doi:10.1029/2004JD005209, 2004.

Dessler, A. E., Schoeberl, M. R., Wang, T., Davis, S. M., and Rosenlof, K. H.: Stratospheric water vapor feedback, P. Natl. Acad. Sci., 110, 18087-18091, 2013.

Dethof, A., O'Neill, A., Slingo, J., and Smit, H.: A mechanism for moistening the lower stratosphere involving the Asian summer monsoon, Q. J. Roy. Meteor. Soc., 125, 1079-1106, 1999.

Devasthale, A. and Fueglistaler, S.: A climatological perspective of deep convection penetrating the TTL during the Indian summer monsoon from the AVHRR and MODIS instruments, Atmos. Chem. Phys., 10, 4573-4582, doi:10.5194/acp-10-45732010, 2010.

Dunkerton, T. J.: Evidence of meridional motion in the summer lower stratosphere adjacent to monsoon regions, J. Geophys. Res.-Atmos., 100, 16675-16688, doi:10.1029/95jd01263, 1995.

Dvortsov, V. L. and Solomon, S.: Response of the stratospheric temperatures and ozone to past and future increases in stratospheric humidity, J. Geophys. Res.-Atmos., 106, 7505-7514, 2001.

ECMWF: ERA-Interim reanalysis data, available at: https://software.ecmwf.int/wiki/display/WEBAPI/Access+ ECMWF+Public+Datasets (last access: June 2015), 2011.

Evans, S. J., Toumi, R., Harries, J. E., Chipperfield, M. R., and Russell, J. M.: Trends in stratospheric humidity and the sensitivity of ozone to these trends, J. Geophys. Res.-Atmos., 103, 8715-8725, 1998.

Forster, F., Piers, M., and Shine, K. P.: Stratospheric water vapour changes as a possible contributor to observed stratospheric cooling, Geophys. Res. Lett., 26, 3309-3312, 1999.

Fu, R., Hu, Y., Wright, J. S., Jiang, J. H., Dickinson, R. E., Chen, M., Filipiak, M., Read, W. G., Waters, J. W., and Wu, D. L.: Short circuit of water vapor and polluted air to the global stratosphere by convective transport over the Tibetan Plateau, P. Natl. Acad. Sci., 103, 5664-5669, 2006.

Fueglistaler, S., Bonazzola, M., Haynes, P., and Peter, T.: Stratospheric water vapor predicted from the Lagrangian temperature history of air entering the stratosphere in the tropics, J. Geophys. Res.-Atmos., 110, D08107, doi:10.1029/2004JD005516, 2005.

Gautam, R., Hsu, N. C., Lau, K.-M., and Kafatos, M.: Aerosol and rainfall variability over the Indian monsoon region: distributions, trends and coupling, Ann. Geophys., 27, 3691-3703, doi:10.5194/angeo-27-3691-2009, 2009.

Gettelman, A., Salby, M. L., and Sassi, F.: Distribution and influence of convection in the tropical tropopause region, J. Geophys Res.-Atmos., 107, ACL 6-1-ACL 6-12, 2002. 
Gettelman, A., Kinnison, D. E., Dunkerton, T. J., and Brasseur, G. P.: Impact of monsoon circulations on the upper troposphere and lower stratosphere, J. Geophys. Res.-Atmos., 109, D22101, doi:10.1029/2004JD004878, 2004.

Goswami, B. N., Venugopal, V., Sengupta, D., Madhusoodanan, M., and Xavier, P. K.: Increasing trend of extreme rain events over India in a warming environment, Science, 314, 1442-1445, 2006.

Holton, J. R. and Gettelman, A.: Horizontal transport and the dehydration of the stratosphere, Geophys. Res. Lett., 28, 2799-2802, 2001.

Holton, J. R., Haynes, P. H., McIntyre, M. E., Douglass, A. R., Rood, R. B., and Pfister, L.: Stratosphere-troposphere exchange, Rev. Geophys., 33, 403-439, doi:10.1029/95RG02097, 1995.

Jackson, D., Driscoll, S., Highwood, E., Harries, J., and Russell, J.: Troposphere to stratosphere transport at low latitudes as studies using HALOE observations of water vapour 1992-1997, Q. J. Roy. Meteor. Soc., 124, 169-192, 1998.

James, R., Bonazzola, M., Legras, B., Surbled, K., and Fueglistaler, S.: Water vapor transport and dehydration above convective outflow during Asian monsoon, Geophys. Res. Lett., 35, L20810, doi:10.1029/2008g1035441, 2008.

Kikuchi, K., Wang, B., and Kajikawa, Y.: Bimodal representation of the tropical intraseasonal oscillation, Clim. Dynam., 38, 19892000, 2012.

Lau, K.-M. and Chan, P.: Aspects of the 40-50 day oscillation during the northern summer as inferred from outgoing longwave radiation, Mon. Weather Rev., 114, 1354-1367, 1986.

Lawrence, D. M. and Webster, P. J.: The boreal summer intraseasonal oscillation: Relationship between northward and eastward movement of convection, J. Atmos. Sci., 59, 1593-1606, 2002.

Livesey, N. J., Read, W. G., Froidevaux, L., Lambert, A., Manney, G. L., Pumphrey, H. C., Santee, M. L., Schwartz, M. J., Wang, S., and Cofield, R. E.: Version 3.3 Level 2 data quality and description document, JPL D-33509, Tech. Rep., Jet Propul. Lab., Calif. Inst. of Technol., Pasadena, CA, USA, 2011.

Milz, M., Von Clarmann, T., Fischer, H., Glatthor, N., Grabowski, U., Höpfner, M., Kellmann, S., Kiefer, M., Linden, A., and Mengistu Tsidu, G.: Water vapor distributions measured with the Michelson Interferometer for Passive Atmospheric Sounding on board Envisat (MIPAS/Envisat), J. Geophys. Res.-Atmos., 110, D24307, doi:10.1029/2005JD005973, 2005.

NASA: The MLS $\mathrm{H}_{2} \mathrm{O}$ Product, available at: http://mls.jpl.nasa. gov/products/h2o_product.php (last access: June 2015), 2011.

NOAA: Interpolated OLR dataset, available at: http://www.esrl. noaa.gov/psd/data/gridded/data.interp_OLR.html (last access: May 2014), 1996.

Park, M., Randel, W. J., Gettelman, A., Massie, S. T., and Jiang, J. H.: Transport above the Asian summer monsoon anticyclone inferred from Aura Microwave Limb Sounder tracers, J. Geophys. Res.-Atmos., 112, D16309, doi:10.1029/2006JD008294, 2007.

Park, M., Randel, W. J., Emmons, L. K., and Livesey, N. J.: Transport pathways of carbon monoxide in the Asian summer monsoon diagnosed from Model of Ozone and Related Tracers (MOZART), J. Geophys. Res.-Atmos., 114, D08303, doi:10.1029/2008JD010621, 2009.

Ploeger, F., Günther, G., Konopka, P., Fueglistaler, S., Müller, R., Hoppe, C., Kunz, A., Spang, R., Grooß, J. U., and Riese, M.: Horizontal water vapor transport in the lower stratosphere from subtropics to high latitudes during boreal summer, J. Geophys. Res.-Atmos., 118, 8111-8127, doi:10.1002/jgrd.50636, 2013.

Ploeger, F., Gottschling, C., Griessbach, S., Grooß, J.-U., Guenther, G., Konopka, P., Müller, R., Riese, M., Stroh, F., Tao, M., Ungermann, J., Vogel, B., and von Hobe, M.: A potential vorticitybased determination of the transport barrier in the Asian summer monsoon anticyclone, Atmos. Chem. Phys., 15, 13145-13159, doi:10.5194/acp-15-13145-2015, 2015.

Qian, W. and Lee, D.-K.: Seasonal march of Asian summer monsoon, Int. J. Climatol., 20, 1371-1386, 2000.

Ramanathan, V., Chung, C., Kim, D., Bettge, T., Buja, L., Kiehl, J., Washington, W., Fu, Q., Sikka, D., and Wild, M.: Atmospheric brown clouds: Impacts on South Asian climate and hydrological cycle, P. Natl. Acad. Sci. USA, 102, 5326-5333, 2005.

Randel, W. J., Wu, F., Gettelman, A., Russell, J. M., Zawodny, J. M., and Oltmans, S. J.: Seasonal variation of water vapor in the lower stratosphere observed in Halogen Occultation Experiment data, J. Geophys. Res.-Atmos., 106, 14313-14325, 2001.

Randel, W. J., Zhang, K., and Fu, R.: What controls stratospheric water vapor in the $\mathrm{NH}$ summer monsoon regions?, J. Geophys. Res.-Atmos., 120, 7988-8001, doi:10.1002/2015JD023622, 2015.

Rienecker, M. M., Suarez, M. J., Gelaro, R., Todling, R., Bacmeister, J., Liu, E., Bosilovich, M. G., Schubert, S. D., Takacs, L., and Kim, G.-K.: MERRA: NASA's modern-era retrospective analysis for research and applications, J. Climate, 24, 3624-3648, 2011.

Rosenlof, K. H., Tuck, A. F., Kelly, K. K., Russell, J. M., and McCormick, M. P.: Hemispheric asymmetries in water vapor and inferences about transport in the lower stratosphere, J. Geophys. Res.-Atmos., 102, 13213-13234, 1997.

Schoeberl, M. R. and Dessler, A. E.: Dehydration of the stratosphere, Atmos. Chem. Phys., 11, 8433-8446, doi:10.5194/acp11-8433-2011, 2011.

Schoeberl, M. R., Dessler, A. E., and Wang, T.: Simulation of stratospheric water vapor and trends using three reanalyses, Atmos. Chem. Phys., 12, 6475-6487, doi:10.5194/acp-12-6475-2012, 2012.

Schoeberl, M. R., Dessler, A. E., and Wang, T.: Modeling upper tropospheric and lower stratospheric water vapor anomalies, Atmos. Chem. Phys., 13, 7783-7793, doi:10.5194/acp-13-77832013, 2013.

Schoeberl, M. R., Dessler, A. E., Wang, T., Avery, M. A., and Jensen, E. J.: Cloud formation, convection, and stratospheric dehydration, Earth and Space Sci., 1, 1-17, doi:10.1002/2014EA000014, 2014.

Shindell, D. T.: Climate and ozone response to increased stratospheric water vapor, Geophys. Res. Lett., 28, 1551-1554, 2001.

Solomon, S., Rosenlof, K. H., Portmann, R. W., Daniel, J. S., Davis, S. M., Sanford, T. J., and Plattner, G.-K.: Contributions of stratospheric water vapor to decadal changes in the rate of global warming, Science, 327, 1219-1223, 2010.

Stenke, A. and Grewe, V.: Simulation of stratospheric water vapor trends: impact on stratospheric ozone chemistry, Atmos. Chem. Phys., 5, 1257-1272, doi:10.5194/acp-5-1257-2005, 2005.

Turner, A. G. and Annamalai, H.: Climate change and the South Asian summer monsoon, Nature Climate Change, 2, 587-595, 2012.

Walker, J. M., Bordoni, S., and Schneider, T.: Interannual variability in the large-scale dynamics of the South Asian summer 
monsoon, J. Climate, 28, 3731-3750, doi:10.1175/JCLI-D-14$00612.1,2015$.

Wang, T., Randel, W. J., Dessler, A. E., Schoeberl, M. R., and Kinnison, D. E.: Trajectory model simulations of ozone $\left(\mathrm{O}_{3}\right)$ and carbon monoxide $(\mathrm{CO})$ in the lower stratosphere, Atmos. Chem. Phys., 14, 7135-7147, doi:10.5194/acp-14-7135-2014, 2014.

Wang, T., Dessler, A. E., Schoeberl, M. R., Randel, W. J., and Kim, J.-E.: The impact of temperature vertical structure on trajectory modeling of stratospheric water vapor, Atmos. Chem. Phys., 15, 3517-3526, doi:10.5194/acp-15-3517-2015, 2015.
Wright, J. S., Fu, R., Fueglistaler, S., Liu, Y. S., and Zhang, Y.: The influence of summertime convection over Southeast Asia on water vapor in the tropical stratosphere, J. Geophys. Res.-Atmos., 116, D12302, doi:10.1029/2010JD015416, 2011.

Zuo, Z., Yang, S., Zhang, R., Jiang, P., Zhang, L., and Wang, F.: Long-term variations of broad-scale Asian summer monsoon circulation and possible causes, J. Climate, 26, 8947-8961, 2013. 